\title{
Comparative analyses of stevioside between fresh leaves and in-vitro derived callus tissue from Stevia rebaudiana Bert. using HPLC
}

\author{
S. Mahmud ${ }^{1^{*}}$, S. Akter ${ }^{2}$, I. A. Jahan ${ }^{3}$, S. Khan², A. Khaleque ${ }^{2}$ and S. Islam² \\ ${ }^{1}$ Department of Biochemistry and Microbiology, North South University, Dhaka-1229. \\ ${ }^{2}$ Plant Tissue Culture Section, Biological Research Division, Bangladesh Council of Scientific and Industrial \\ Research, Dhanmondi, Dhaka-1205. \\ ${ }^{3}$ Chemical Research Division BCSIR Labroratories, Dhaka-1205.
}

\begin{abstract}
A protocol was developed to produce large amount of callus in short a period of time from leaf explants of Stevia rebaudiana Bert. The highest amount of white callus was obtained on MS medium supplemented with $2.5 \mathrm{mg} / \mathrm{l}$ 2, 4-D and $0.5 \mathrm{mg} / \mathrm{l} \mathrm{BAP}$ after 3 weeks of inoculating leaf segments. On the other hand, $0.5 \mathrm{mg} / \mathrm{l} \mathrm{BAP}$ and $1.0 \mathrm{mg} / \mathrm{l} \mathrm{Kn}$ exhibits poor performance towards callus formation while after using $1.0 \mathrm{mg} / \mathrm{l} \mathrm{Kn}$ alone did not develop any callus. In this experiment, highest amount of green callus was obtained when MS medium supplemented with $2.5 \mathrm{mg} / \mathrm{l} \mathrm{NAA}$ and $10 \%$ coconut water was used. An improved analytical method HPLC was applied to analyze stevioside extracted from the leaf and callus of Stevia rebaudiana. The stevioside in each sample were analyzed by comparing their retention times with those of the standards. The retention time (RT) of stevioside for leaves were found 14.96 and for callus 13.81 mins. The percentage of stevioside content from leaves and callus was $12.19 \%$ and $12.62 \%$ respectively
\end{abstract}

Key words: Stevioside; Callus; Natural sweeteners; Growth regulators; Stevia rebaudiana; HPLC

\section{Introduction}

Stevia rebaudiana Bertoni a perennial shrub belongs to Asteraceae family grown commercially in many parts of Brazil, Paraguay, Central America, Israel, Thailand, Korea and China (Soejarto et al., 1983). The leaves of Stevia have a pleasantly sweet, refreshing taste that can linger in the mouth for hours. The material contains the sweet components, surrounded by the bitter components in the veins (Maiti and Purohit, 2008). According to World Health Organization (WHO) findings it regulates blood pressure, fights cavities, induces pancreas to produce more insulin, and act as bactericidal agent (Bhosle, 2004). No negative clinical reports have appeared in any of these countries where Stevia is readily available. Yoshikawa and co-workers (Yoshikawa et al., 1979) who found from extracted stevia leaves that stevioside had slight bitterness, some astringency after taste and showed fairly low general acceptability among the 4 diterpene glycosides. The Paraguayan botanist M.S. Bertoni first botanically described Stevia rebaudiana (Lewis 1992). Stevia is a newly cultivated in Bangladesh. The climatic requirements of this tropical elite medicinal plant indicate that it can be introduced in the hilly areas of Sylhet and Chittagong (Uddin et al., 2006). Moreover, the unique selling points of stevia sweetener are very strong in Bangladesh due to the presence of diabetes and other metabolic diseases including obesity (Uddin et al. 2006). These beneficial effects focused the importance of Stevia and its availability throughout the year but the problem is stevioside content depends on biomass yield and methods of cultivation but in general percentage of seed germination in Stevia is often poor and requires long time to establish seedlings reported by Nepovim and co-workers (Nepovim et al., 1998) and Geuns (2003). Therefore, there are basically two options for multiplication. The first is the tissue culture and second the stem cutting. Callus culture is a good option because further embryogenesis or plant regeneration can be obtained (Swanson et al.,1992, Yamazaki et al., 1991, Patel et al., 2009, Bondarev et al., 1998). Eight diterpene glycosides with sweetening properties have been identified in leaf tissues of Stevia Yadav et al., 2011). Among them, Stevioside is the predominant sweetener, accounting for $3-8 \%$ (w/w) of dried leaves with sweetening power 300 times that of sucrose and is known to be non-caloric ( Bridel et al.,1931). Its leaves and extracts are widely used as health food in tea bags, tablets, soft drinks, sea food, dessert items and confectionaries in recent years in Japan and South America. Use of Stevioside as a natural sweetener has been reported to be safe (Geuns, 2004). Various methods have been described for the estimation of stevioside content in stevia leaves including enzymatic determination, near infrared reflectance spectroscopy (NIRS) and HPLC 
(Mizukami et al., 1982, Nishiyama et al. Ahmed and Dobberstein developed an HPLC method for the determination of eight diterpene glycosides. Satisfactory resolution was achieved on two protein columns in series, after the plant material was extracted with chloroform prior to methanol extraction (Mizukami et al., 1982). Therefore, considering its scope and future need of planting material, the present study was undertaken to find out suitable concentration and combination of cytokinin (BAP) and auxins (NAA, 2, 4-D, Kn) for callus induction and development from leaf explants, to study the production of steviol glycosides in callus culture and to compare the amount of stevioside between induced callus and leaf tissue using HPLC.

\section{Materials and methods}

The experiment was conducted at Tissue Culture Section, Bangladesh Council of Scientific and Industrial Research (BCSIR), Dhaka Bangladesh. The experiment was performed in two phases. In the first phase, leaf segments of Stevia rebaudiana, as explants were cultured for callus induction on MS medium (Murashige and Skoog, 1962) supplemented with auxins (2,4-D, NAA) and cytokinin (BAP, Kn) at different concentrations $(0.5,1.0,1.5,2.0,2.5,3.0 \mathrm{mg} / \mathrm{l})$ and with $10 \%$ coconut water respectively. Regular visual observation was done up to five weeks to record the day of callus initiation and maturation. Then fresh weight of best calluses and fresh leaves were recorded.

In the second phase of this study stevioside content was determined in the callus and leaf from which the callus was developed by HPLC method. The HPLC system was a SHIMADJU SPD-M20A chromatograph equipped with a binary pump and UV detection was at $219 \mathrm{am}$. The analytical column was RP-C18 (250 mm X $4.6 \mathrm{~nm}$ ). Separation was performed with a water and methanol (65:35) solvent system as the elusion solvent at flow rate $1 \mathrm{ml} / \mathrm{min}$.

Methanol was added to leaf sample $(0.3601 \mathrm{~g})$ at a ratio $(1: 4$, w/v), vortexed for 30 minutes and kept for 4 hours. Then filtered through Whatman NO-4 filter paper and the residue was again extracted following the same procedure. Both the filtrates were combined together and evaporated to dryness at reduces pressure by using rotary evaporator at $45^{\circ} \mathrm{C}$. The residue after evaporation of methanol was washed with n-hexane thrice and then extracted with 1-Butanol thrice. The 1-Butanol soluble extract was then evaporated to dryness at reduced pressure and then freeze dried. A $0.201 \mathrm{~g}$ dry extract (sample -1) was obtained and $0.10 \mathrm{~g}$ of sample-1 was dissolved in analytical grade $(1 \mathrm{ml})$ methanol and filtered through $0.2 \mu$ nylon syring filter. The filtreate was used as stock solution for HPLC analysis.
$1.0620 \mathrm{~g}$ of callus sample was extracted following the same procedure as above and $0.50 \mathrm{~g}$ of dry extract (sample-2) was obtained. $0.3001 \mathrm{~g}$ of the saple- 2 was then dissolved in analytical grade methanol $(9 \mathrm{ml})$ and filtered as above. This solution of callus (saple-2) was used as stock solution for its HPLC analysis.

\section{Result and discussion}

In this study leaf explants were excised from the plant species of Stevia rebaudiana as explants sources. Several experiments were carried out to obtain an efficient media for production of callus from leaf segments and analysis of stevioside from the fresh leaves and callus tissue. Callus initiation was observed within 5 days after inoculation and most of the treatments showed callus formation within 5 weeks. Maximum amount of callusing was observed on the MS medium supplemented with combination of $2.5 \mathrm{mg} / \mathrm{l} \mathrm{2}$, 4-D and $0.5 \mathrm{mg} / 1 \mathrm{BAP}$ after 3 weeks of culture initiation (Fig.1-c). In this medium, calluses were globular and whitish in colour and average sizes of these calluses were $1.80 \mathrm{~cm}$ (Table I). On the other hand, poor most and no callusing observed when leaf explants were cultured in MS medium containing 0.5-1.5mg/l BAP + 0.5-1.5 mg/l Kn combination and $1.0 \mathrm{mg} / \mathrm{l} \mathrm{Kn}$ alone respectively. Maximum amount of green calluses were found in the MS medium supplemented with $2.5 \mathrm{mg} / \mathrm{l} \mathrm{NAA}$ and $10 \%$ of coconut water and average sizes of the calluses were $2.50 \mathrm{~cm}$ (Table I). MS medium containing $2 \mathrm{mg} / \mathrm{l} \mathrm{BAP}+2.0 \mathrm{mg} / \mathrm{l} \mathrm{NAA}$ was found to be the best for callus induction was reported by Patel et al., (2009). Bespalhok et al., (1997) reported that MS media supplemented with $2 \mathrm{mg} / \mathrm{l}$ 2,4-D developed pale green colored callus from leaf segments. In the second part of study, analysis of stevioside was carried out from the leaf powder and callus powder in HPLC. In the present experiment, identification and quantification of stevioside content in the samples was done by comparing the retention time, UV spectra and peak area of sample with that of the standard. Calibration curve for stevioside was constructed in the concentration range of 0.1 to $1.0 \mathrm{mg} / \mathrm{ml}$. The retention time (RT) of stevioside for leaves were found to be $14.96 \mathrm{~min}$ and for callus $13.81 \mathrm{~min}$ (Fig.2). The stevioside content of the samples, leaves and callus was found to be $12.19 \%$ and $12.62 \%$ respectively (Table II). By analyzing the peaks for leaf and callus it can be concluded that the callus possessed better amount of stevioside than the leaf. Stevioside extractions from stevia leaves analyzed by HPLC in which the highest amount of stevioside $(23.20 \%)$ was obtained in methanol extract reported by Esmat and co-workers (Esmat et al., 2010). 

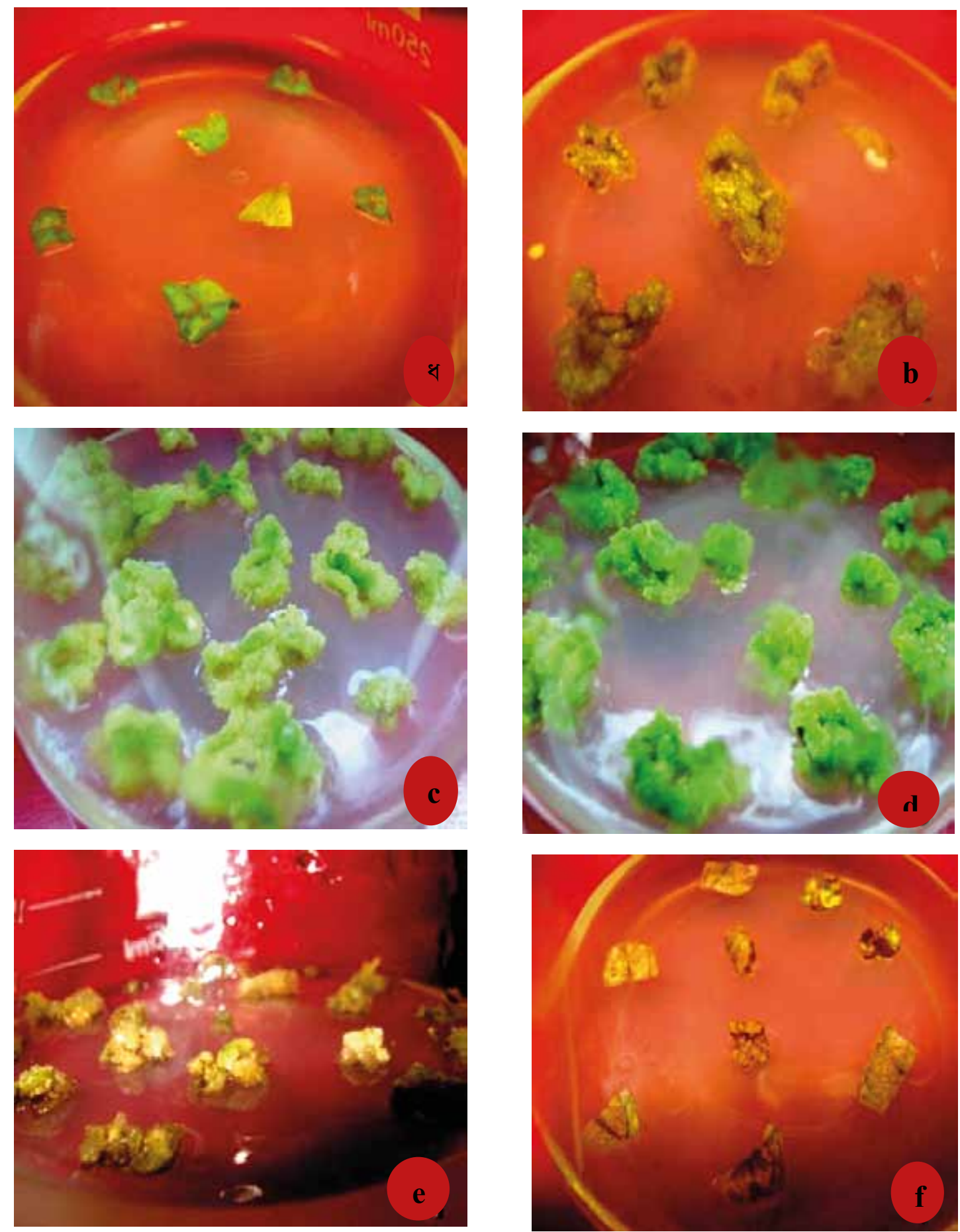

Fig. 1: Callus induction of Stevia rebaudiana. a) Inoculation of leaf segments, b-f) Different types of callus formation in MS supplemented with b) $0.5 \mathrm{mg} / \mathrm{l}$ NAA \& $0.5 \mathrm{mg} / \mathrm{l}$ BAP, c) $2.5 \mathrm{mg} / \mathrm{l}$ 2, 4-D \& $0.5 \mathrm{mg} / \mathrm{l}$ BAP, d) $2.5 \mathrm{mg} / \mathrm{l} \mathrm{NAA+10 \%}$ coconut water, e) $0.5 \mathrm{mg} / \mathrm{l} \mathrm{Kn} \mathrm{\&} 0.5 \mathrm{mg} / \mathrm{l}$ BAP, f) $3.0 \mathrm{mg} / \mathrm{l}$ 2,4-D and $1.0 \mathrm{mg} / \mathrm{l} \mathrm{Kn}$. 
Table I: Production of callus from leaf explants of Stevia rebaudiana on MS medium containing different concentrations and combinations of growth regulators

\begin{tabular}{|c|c|c|c|c|c|c|}
\hline \multirow{2}{*}{$\begin{array}{l}\text { Growth Regulators } \\
\text { Growth } \\
\text { Regulators }\end{array}$} & \multicolumn{2}{|c|}{$\begin{array}{l}\text { Inoculated } \\
\text { leaf size }\end{array}$} & $\begin{array}{l}\text { Amount of callus } \\
\text { responded }\end{array}$ & $\begin{array}{l}\text { Avg. size of callus } \\
\text { (20observations) }\end{array}$ & \multirow{2}{*}{$\begin{array}{r}\begin{array}{c}\text { Colour } \\
\text { of callus }\end{array} \\
\text { Texture } \\
\text { of callus }\end{array}$} & \multirow[t]{2}{*}{$\begin{array}{l}\text { Texture } \\
\text { of callus }\end{array}$} \\
\hline & $\begin{array}{l}\text { Inoculat } \\
\text { ed leaf } \\
\text { size }\end{array}$ & $\begin{array}{l}\text { Amount of } \\
\text { callus } \\
\text { responded }\end{array}$ & $\begin{array}{l}\text { Avg. size of } \\
\text { callus }\end{array}$ & $\begin{array}{l}\text { Colour } \\
\text { of callus }\end{array}$ & & \\
\hline $\mathrm{NAA}+\mathrm{BAP}$ & & & & & & \\
\hline $\begin{array}{l}0.5+0.5 \mathrm{mg} / 1 \\
0.5+1.0 \mathrm{mg} / 1 \\
1.0+1.0 \mathrm{mg} / 1 \\
1.5+1.5 \mathrm{mg} / 1\end{array}$ & $\begin{array}{l}1.00 \mathrm{~cm} \\
0.75 \mathrm{~cm} \\
1.25 \mathrm{~cm} \\
1.50 \mathrm{~cm}\end{array}$ & $\begin{array}{l}\text { Medium } \\
\text { Poor } \\
\text { Highest } \\
\text { Highest }\end{array}$ & $\begin{array}{l}1.50 \mathrm{~cm} \\
1.00 \mathrm{~cm} \\
2.50 \mathrm{~cm} \\
2.75 \mathrm{~cm}\end{array}$ & $\begin{array}{l}\text { Brownish } \\
\text { Whitish } \\
\text { Pale green } \\
\text { Greenish }\end{array}$ & Compact & \\
\hline $\begin{array}{l}2,4-\mathrm{D}+\mathrm{BAP} \\
0.5+1.0 \mathrm{mg} / \mathrm{l} \\
1.0+1.0 \mathrm{mg} / \mathrm{l} \\
2.5+0.5 \mathrm{mg} / \mathrm{l} \\
3.0+2.0 \mathrm{mg} / \mathrm{l}\end{array}$ & $\begin{array}{l}1.00 \mathrm{~cm} \\
0.75 \mathrm{~cm} \\
1.50 \mathrm{~cm} \\
1.00 \mathrm{~cm}\end{array}$ & $\begin{array}{l}\text { Medium } \\
\text { Poor } \\
\text { Highest } \\
\text { Medium }\end{array}$ & $\begin{array}{l}1.50 \mathrm{~cm} \\
1.0 \mathrm{~cm} \\
1.80 \mathrm{~cm} \\
1.75 \mathrm{~cm}\end{array}$ & $\begin{array}{l}\text { Brownish } \\
\text { Whitish } \\
\text { Whitish } \\
\text { Pale green }\end{array}$ & Compact & \\
\hline $\begin{array}{l}\mathrm{Kn}+\mathrm{BAP} \\
0.5+0.5 \mathrm{mg} / \mathrm{l} \\
1.0+1.0 \mathrm{mg} / \mathrm{l} \\
1.5+1.5 \mathrm{mg} / \mathrm{l}\end{array}$ & $\begin{array}{l}1.00 \mathrm{~cm} \\
1.30 \mathrm{~cm} \\
1.00 \mathrm{~cm}\end{array}$ & $\begin{array}{l}\text { No callus } \\
\text { formed } \\
\text { No callus } \\
\text { formed } \\
\text { Poor }\end{array}$ & $\begin{array}{l}------- \\
------ \\
1.25 \mathrm{~cm}\end{array}$ & $\begin{array}{c}------- \\
\text { Brownish }\end{array}$ & Compact & \\
\hline $\begin{array}{r}\mathrm{NAA} \\
0.5 \mathrm{mo} / 1\end{array}$ & $1.00 \mathrm{~cm}$ & & --------- & ---------- & & \\
\hline $\begin{array}{l}1.0 \mathrm{mg} / \mathrm{l}+10 \% \\
\text { coconut water }\end{array}$ & $1.25 \mathrm{~cm}$ & Medium & $1.50 \mathrm{~cm}$ & Brownish & & \\
\hline $\begin{array}{l}2.0 \mathrm{mg} / \mathrm{l} \\
2.5 \mathrm{mg} / \mathrm{l}+10 \% \\
\text { coconut water }\end{array}$ & $1.00 \mathrm{~cm}$ & Medium & $1.50 \mathrm{~cm}$ & Brownish & & \\
\hline $\begin{array}{l}2,4-\mathrm{D} \\
0.5 \mathrm{mg} / \mathrm{l} \\
2.0 \mathrm{mg} / \mathrm{l} \\
3.0 \mathrm{mg} / \mathrm{l}\end{array}$ & $\begin{array}{l}1.00 \mathrm{~cm} \\
0.85 \mathrm{~cm} \\
1.25 \mathrm{~cm}\end{array}$ & $\begin{array}{l}\text { Poor } \\
\text { Poor } \\
\text { Medium }\end{array}$ & $\begin{array}{l}1.50 \mathrm{~cm} \\
1.00 \mathrm{~cm} \\
1.50 \mathrm{~cm}\end{array}$ & $\begin{array}{l}\text { Black } \\
\text { Black } \\
\text { Brownish }\end{array}$ & & \\
\hline $\begin{array}{c}\mathrm{Kn} \\
0.5 \mathrm{mg} / \mathrm{l} \\
1.0 \mathrm{mg} / \mathrm{l} \\
1.5 \mathrm{mg} / \mathrm{l}\end{array}$ & $\begin{array}{l}0.75 \mathrm{~cm} \\
1.00 \mathrm{~cm} \\
0.50 \mathrm{~cm}\end{array}$ & $\begin{array}{l}\text { Poor } \\
\text { No callus } \\
\text { formed } \\
\text { No callus } \\
\text { formed }\end{array}$ & $\begin{array}{c}1.00 \mathrm{~cm} \\
------ \\
------\end{array}$ & $\begin{array}{l}\text { Brownish } \\
\text {------- } \\
\text {------- }\end{array}$ & $\begin{array}{c}\text { Compact } \\
\text {------- } \\
\text {------- }\end{array}$ & \\
\hline
\end{tabular}



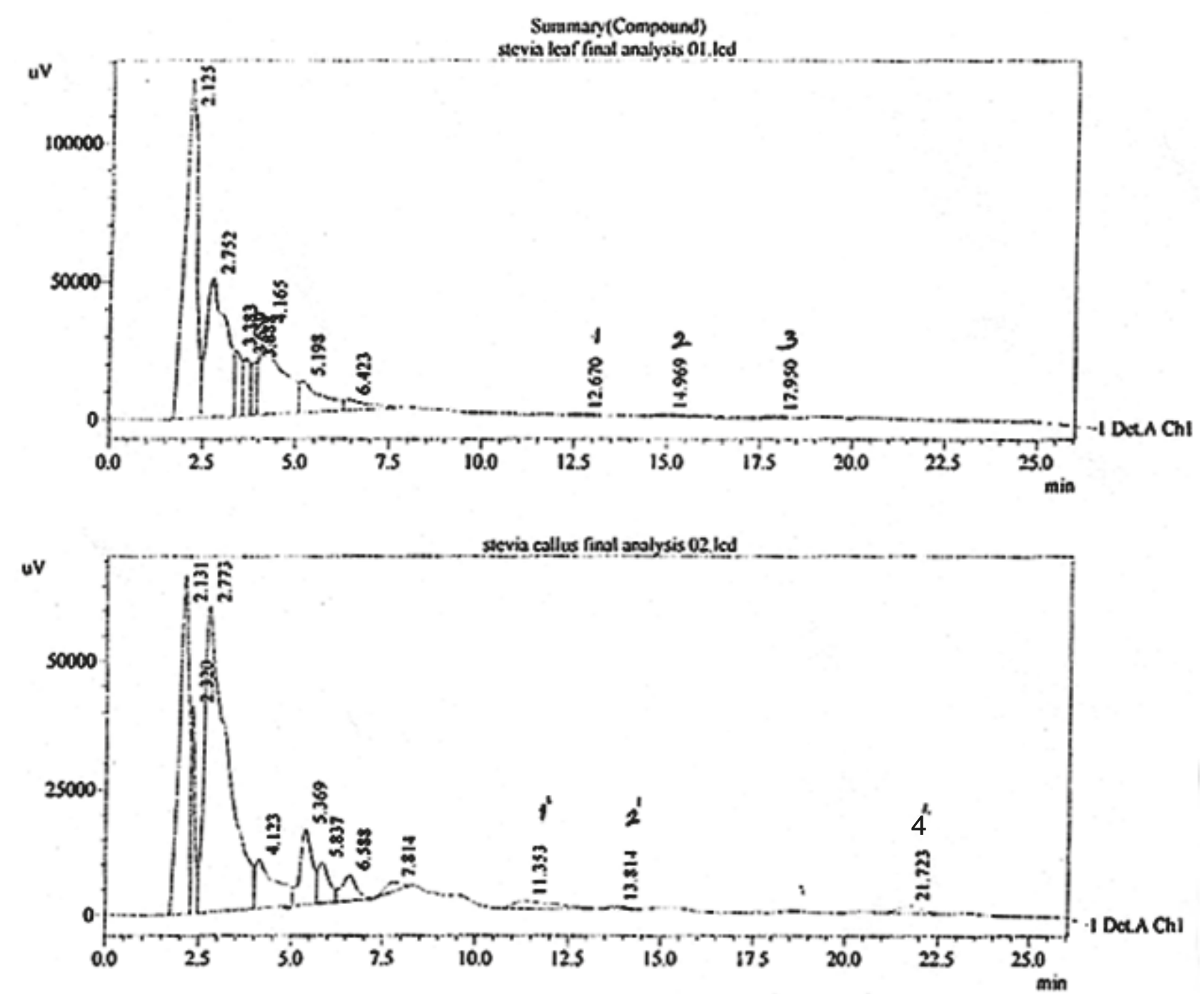

Fig. 2: Analysis of stevioside from Stevia rebaudiana fresh leaves and callus using HPLC.

\section{References}

Bespalhok, J.C. Hashimoto, J.M. and Vieira, L.G.E. (1993). Induction of somatic embryogenesis from leaf explants of Stevia rebaudiana. R. Bras. Fisiol. Veg. 5(1): 51-53.

Bhosle, S. (2004), Commercial Cultivation of Stevia rebaudiana, Agrobios Newsletter; 3 (2): 43-45.

Bondarev, N.I. Nosov, A.M. Kornienko, A.V. (1998), Effects of exogenous growth regulators on callusogenesis and growth of cultured cells of Stevia rebaudiana Bertoni, Russ. J. Plant Physiol; 45: 888-892.
Bridel, M. and Lavieille, R. (1931), The sweet principle of Kaa-he-e (Stevia rebaudiana). J Pharm Clin; 14: 636-655.

Esmat, A. Abou-Arab, A. Azza Abou-Arab and Ferial Abu-Salem, M. (2010), Physico-chemical assessment of natural sweeteners steviosides produced from Stevia rebaudiana Bert. plant. African Journal of Food Science, 4(5): 269- 281.

Geuns, J.M.C. (2004), Review: The safety of stevioside used as a sweetener. In: Proc. first symposium on the Safety of Stevioside. Geuns, J.M.C. and Buyse, J., Eds. Kuleuven. Euprint Editions ISBN 9074253024, p. 127 
Lewis, W.H. (1992), Early uses of Stevia rebaudiana leaves as sweetener In Paraguay. Econ. Bot; 46: 336-337.

Maiti, R.K. Purohi,t S.S. (2008), Stevia: A miracle plant for human health. Agrobios (India) Jodhpur, India. ISBN: 9788177543384.

Mizukami, H. Shiiba, K. and Ohashi, H. (1982). Enzymatic determination of stevioside in Stevia rebaudiana. Phytochemistry; 21: 1927-1930.

Murashige, T. and Skoog, F. (1962), A revised medium for rapid growth and bio-assays with Stevia tissue cultures. Journal of Plant Physiology; 15: 473-497.

Nepovim, A. and Vanek, T. (1998), In vitro propagation of Stevia rebaudiana plants using multiple shoot culture. Planta Medica; 64(8): 775-776.

Nikolai, B. Oxana, R. Alexander, N. (2001), Peculiarities of deterpenoid steviol glycoside production in vitro cultures of Stevia rebaudiana Bertoni. Plant Sci.; 161: 155-163.

Patel, R. M. and Shah, R. R. (2009), Regeneration of Stevia Plant Through Callus Culture. Indian Journal of Pharmaceutical Sciences; 71(1): 46-50.

Soejarto, D.D. Compadre, C.M. Medon, P.J. Kamath, S.K. and Kinghorn, A.D. (1983), Potential sweetening agents of plant origin. II. Field search for sweet-tasting Stevia species. Econ. Bot. 37: 71-79.
Swanson, S.M., Mahady, G.B., Beecher, C.W.W. (1992), Stevioside biosynthesis by callus, root, shoot and rooted-shoot cultures in vitro. Plant Cell Tissue Organ Cult.; 28: 151-157.

Tadhani, M.B. Jadeja, R.P. Rena, S. (2006), Micropropagation of Stevia rebaudiana Bertoni using multiple shoot culture. J Cell Tiss Res.; 6: 545-8.

Uddin, M.S. Chowdhury, M.S.H. Khan, M.M.M.H. Ahmed, R. and Baten, M.A. (2006), In vitro propagation of Stevia rebaudiana, Bert. in Bangladesh. African Journal of Biotechnology; 13: 1178-1180.

Yamazaki, T. Flores, H.E. (1991), Examination of steviol glycoside production by hair root and shoot cultures of Stevia rebaudiana. J. Nat. Prod; 54: 986-992.

Yadav, A.K. Singh, S. Dhyani, D. Ahuja, P.S. (2011), A review on the improvement of stevia [Stevia rebaudiana (Bertoni)]. Can. J. Plant Sci.; 91: 1-27.

Yoshikawa, S. Ishima, T. Katayama, O. (1979), Taste of components of stevioside. Am. Chem. Soc.; 177(1): 74

Received: 1 February 2012; Revised: 3 September 2014 Accepted: 22 December 2014 